ks. Marek Saj CSsR

Ius Matrimoniale

$31(2020) \mathrm{nr} 2$

DOI:10.21697/im.2020.31.2.03

Wydział Prawa Kanonicznego UKSW

ORCID 0000-0002-0365-1277

\title{
Soborowe źródła prawa małżeńskiego w Kodeksie prawa kanonicznego z 1983 roku
}

Treść: Wstęp. 1. Konstytucja o liturgii świętej Sacrosanctum Concilium. 2. Konstytucja dogmatyczna o Kościele Lumen gentium. 3. Konstytucja duszpasterska o Kościele w świecie współczesnym Gaudium et spes. 4. Dekret o katolickich Kościołach wschodnich Orientalium Ecclesiarum. 5. Dekret o ekumenizmie Unitatis redintegratio. 6. Dekret o pasterskich zadaniach biskupów w Kościele Christus Dominus. 7. Dekret o apostolstwie świeckich Apostolicam actuositatem. 8. Deklaracja o wychowaniu chrześcijańskim Gravissimum educationis.

\section{Wstęp}

Promulgowany 25 stycznia 1983 roku przez papieża Jana Pawła II Kodeks Prawa Kanonicznego dla Kościoła łacińskiego ${ }^{1}$ jest jednym z owoców reformy Kościoła katolickiego zapoczątkowanej przez papieża Jana XXIII, a związanej z Soborem Watykańskim II. Wcześniej-

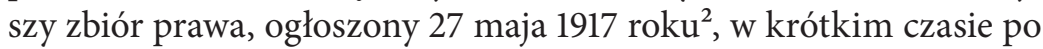

\footnotetext{
1 Codex Iuris Canonici auctoritate Ioannis Pauli PP. II promulgatus. Kodeks Prawa Kanonicznego. Przekład polski zatwierdzony przez Konferencję Episkopatu, Poznań 1984 (dalej: KPK).

${ }^{2}$ Codex Iuris Canonici Pii X Pontificis Maximi iussu digestus Benedicti Papae XV auctoritate promulgatus, Typis Polyglottis Vaticanis 1943.
} 
wejściu w życie stał się niewystarczający, by zaradzić zmieniającym się potrzebom kościelnej rzeczywistości. Wiele norm trzeba było uzupełniać, uaktualniać. Począwszy od lat 20., zaczęły się nawet ukazywać zbiory praw, które wyjaśniały czy uzupełniały kanony kodeksowe. Do Papieskiej Komisji Interpretacyjnej do autentycznego tłumaczenia kanonów Kodeksu coraz częściej wpływały nie tylko zapytania, lecz także spostrzeżenia i propozycje kanonistów co do potrzeby nowej redakcji prawa. Po drugiej wojnie światowej myślano już nie tylko o nowej kodyfikacji, ale w ogóle o odnowie prawa kościelnego. W nowej rzeczywistości świata zastanawiano się też nad rolą i posłannictwem Kościoła, który ciągle należy odnawiać. Dzieła tego podjął się papież Jan XXIII, zwołując Sobór Watykański II, a po jego śmierci kontynuował je papież Paweł VI. W encyklice Ecclesiam suam z 6 sierpnia 1964 pisał: „Zadaniem Soboru Powszechnego będzie, rzecz jasna, powziąć postanowienia, co by należało poprawić i odnowić w ustawodawstwie i karności kościelnej. Zespoły czyli Komisje, które podejmą prace po Soborze, a przede wszystkim Komisja dla Rewizji Prawa Kanonicznego, która już została ustanowiona, będą się starały nadać pewną i ostateczną formę uchwałom Soboru Powszechnego"3. W związku z tym, prace nad nowym Kodeksem odłożono do czasu zakończenia Soboru. Jego owoce, czyli 16 obszernych konstytucji, dekretów i deklaracji, miały być fundamentem dla nowego prawodawstwa kościelnego.

Dokumenty te w dużej mierze stały się więc źródłem prawa kodeksowego, w tym interesującego nas tutaj małżeńskiego. Z czterech konstytucji takie źródło stanowią trzy (Sacrosanctum Concilium, Lumen gentium i Gaudium et spes), z dziewięciu dekretów - cztery (Orientalium Ecclesiarum, Unitatis redintegratio, Christus Dominus i Apostolicam actuositatem), i jedna z trzech deklaracji (Gravissimum educationis). W sumie w kodeksowym prawie małżeńskim można znaleźć 34 odniesienia do dokumentów soborowych.

3 PAweŁ VI, Encyklika Ecclesiam suam, 6 sierpnia 1964, w: JAN XXIII, PAWEŁ VI, Jan PAWeŁ II, Encykliki, Warszawa 1981, nr 44. 
Zawarte jest ono w części I księgi IV: „Uświęcające zadanie Kościoła”. Część ta, zatytułowana „Sakramenty”, podzielona jest na siedem tytułów. Tytuł VII, „Małżeństwo”, liczy 10 rozdziałów (poprzedzonych kanonami wprowadzającymi, kan. 1055-1062): I: „Pasterska troska i czynności poprzedzające zawarcie małżeństwa”, kan. 1063-1072; II: „Przeszkody zrywające w ogólności”, kan. 1073-1082; III: „Poszczególne przeszkody zrywające”, kan. 1083-1094; IV: „Zgoda małżeńska”, kan. 1095-1107; V: „Forma zawarcia małżeństwa”, kan. 1108-1123; VI: „Małżeństwa mieszane”, kan. 1124-1129; VII: „Małżeństwo zawierane tajnie”, kan. 1130-1133; VIII: „Skutki małżeństwa”, kan. 1134-1140; IX: „Rozłączenie małżonków”, kan. 1141-1155; X: „Uważnienie małżeństwa”, kan. 1156-1165. W niniejszej publikacji interesować nas będą tylko te kanony, których źródłami są dokumenty Soboru Watykańskiego II.

W omawianych tutaj normach dotyczących małżeństwa dokumenty soborowe nie zajmują jako źródła naczelnego miejsca. Pomimo to warto jednak zwrócić uwagę, na jakie instytucje prawne w tej materii wpłynął Sobór Watykański II.

\section{Konstytucja o liturgii świętej Sacrosanctum Concilium}

Pierwsza z konstytucji Soboru Watykańskiego II stała się źródłem czterech kanonów Kodeksu prawa kanonicznego z 1983 roku w części dotyczącej prawa małżeńskiego. Pierwszy z nich to kanon 1063, o trzech numerach. Jedynie ostatni numer jest inspirowany trzema numerami tej konstytucji. Czytamy w nim: „Duszpasterze mają obowiązek troszczyć się o to, aby własna wspólnota kościelna świadczyła pomoc wiernym, dzięki której stan małżeński zachowa ducha chrześcijańskiego i będzie się doskonalił. Ta pomoc winna być udzielana przede wszystkim: 3. przez owocne sprawowanie liturgii małżeństwa, która winna ukazywać, że małżonkowie są znakiem i zarazem uczestniczą w tajemnicy jedności oraz płodnej miłości

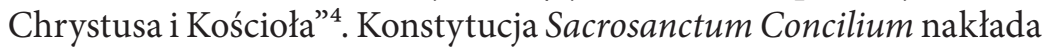

\footnotetext{
${ }^{4}$ Kan. 1063 nr 3 KPK.
} 
więc na duszpasterzy obowiązek troski o liturgiczne wychowanie wiernych i ich czynny udział w liturgii. Ojcowie soborowi nazywają to jednym z ich głównych obowiązków jako szafarzy Bożych tajemnic ${ }^{5}$. $\mathrm{W}$ przywołanym kanonie została podkreślona liturgia sakramentu małżeństwa. Ponieważ ukazuje ona małżonków jako sakramentalny znak jedności Chrystusa i Kościoła, duszpasterze mają zadbać o to, by małżonkowie to rozumieli ${ }^{6}$. Nadto obrzęd zawierania małżeństwa ma być opracowany tak, aby wyraźnie wskazywał na łaskę tego sakramentu?

Kolejny kanon ze źródłem z Sacrosanctum Concilium dotyczy asystowania przy zawieraniu małżeństwa: „Za asystującego przy zawieraniu małżeństwa uważa się tylko tego, kto jest obecny i pyta nowożeńców, czy wyrażają zgodę, i przyjmuje ją w imieniu Kościoła"8. To także jest realizacją soborowego zobowiązania dotyczącego zachowania przepisu, „aby asystujący kapłan pytał zawierających małżeństwo o zgodę i wyrażoną zgodę przyjął"9. Tutaj warto od razu podkreślić wyraźną różnicę: w konstytucji wymieniony jest „kapłan”, zaś w Kodeksie „asystujący”, gdyż oprócz kapłana, czyli ordynariusza i proboszcza w tym przypadku, taką osobą może być również diakon i wierny świecki ${ }^{10}$.

Pozostałe dwa kanony ze wspomnianych czterech, podobnie jak ten rozważany powyżej, znajdują się w rozdziale zatytułowanym „Forma zawarcia małżeństwa”. „Poza wypadkiem konieczności, przy zawieraniu małżeństwa należy zachować obrzędy przepisane w księgach liturgicznych zatwierdzonych przez Kościół albo przyjęte prawnymi zwyczajami”11. „Konferencja Episkopatu może opracować własny

\footnotetext{
5 Por. Sobór Watykański II, Konstytucja o liturgii świętej Sacrosantum Concilium, w: Sobór Waty каŃski II, Konstytucje. Dekrety. Deklaracje, Poznań 2002 (dalej: SC), nr 19.

6 TAMŻE, nr 59.

7 TAMŻE, nr 77.

8 Kan. $1108 \$ 2$ KPK.

9 SC, nr 77.

10 Por. kan. $1108 \$ 1,1112 \S 1-2$ KPK.

11 Kan. 1119 KPK.
} 
obrzęd zawierania małżeństwa, wymagający zatwierdzenia przez Stolicę Świętą, odpowiadający miejscowym i ludowym zwyczajom, przystosowanym do ducha chrześcijańskiego, z zachowaniem jednak prawa, by asystujący, obecny przy zawieraniu małżeństwa, zapytał nupturientów, czy wyrażają zgodę, i tę zgodę przyjął"12. Ich źródła stanowią dwa numery Konstytucji o liturgii świętej: pierwszego numer 78, natomist drugiego 77 i 78. Przywoływany już wcześniej numer 77 dotyczy wymogu zachowywania obrzędów zawierania małżeństwa, zaś 78 odnosi się do sprawowania go, czego potwierdzenie znajdujemy właśnie w odpowiadajacym mu kanonie 1120, zawierającym obowiązek opracowania przez Konferencje Episkopatu własnego obrzędu. Kościół w Polsce opracował więc „Obrzędy sakramentu małżeństwa”, które ówczesna Święta Kongregacja Kultu Bożego zaaprobowała 16 listopada 1972 roku $^{13}$, a ich tekst polski został zatwierdzony przez Konferencję Episkopatu Polski 25 marca 1973 roku$^{14}$. Wydanie to doczekało się kolejnych, ostatniego w 2009 roku $^{15}$.

\section{Konstytucja dogmatyczna o Kościele Lumen gentium}

Treścią Konstytucji dogmatycznej o Kościele jest inspirowanych najwięcej norm kodeksowych. Trzy numery tego dokumentu (11, 29 i 41) wpłynęły na osiem kanonów, które dotyczą różnych kwestii prawa małżeńskiego.

Pierwszy z przywołanych numerów konstytucji wskazuje, jak wiążą wiernych z Kościołem poszczególne sakramenty. W rozważanym tutaj temacie sakramentu małżeństwa przeczytać możemy: „Wreszcie małżonkowie chrześcijańscy, na mocy sakramentu małżeństwa, przez który wyrażają misterium jedności i płodnej miłości

\footnotetext{
12 Kan. 1120 KPK.

13 Sacra Congregatio pro Culto Divino, Poloniae, Prot. 1535/72, 16 novembris 1972, w: Obrzędy sakramentu małżeństwa dostosowane do zwyczajów diecezji polskich, Katowice 1974, s. 6.

14 TAMżE, s. 5.

15 Obrzędy sakramentu małżeństwa dostosowane do zwyczajów diecezji polskich, wydanie trzecie według drugiego wydania wzorcowego, Katowice 2009.
} 
pomiędzy Chrystusem i Kościołem (...), wspierają się wzajemnie w życiu małżeńskim oraz w przyjęciu i wychowaniu potomstwa, celem zdobycia świętości, i tak we właściwym sobie stanie życia i porządku mają własny dar wśród ludu Bożego (...). Z małżeństwa wywodzi się rodzina, w której rodzą się nowi członkowie społeczności ludzkiej, i stają się dzięki łasce Ducha Świętego przez chrzest dziećmi Bożymi, aby lud trwał przez wieki. W tym niejako domowym Kościele rodzice słowem i przykładem powinni być dla swoich dzieci pierwszymi zwiastunami i pielęgnować właściwe każdemu z nich powołanie”16. Treść tę widzimy w kanonie $1055 \$ 1$ : „Małżeńskie przymierze, przez które mężczyzna i kobieta tworzą ze sobą wspólnotę całego życia, skierowaną ze swej natury do dobra małżonków oraz do zrodzenia i wychowania potomstwa, zostało między ochrzczonymi podniesione przez Chrystusa Pana do godności sakramentu”, oraz w kanonie 1136: „Rodzice mają najcięższy obowiązek i najpierwsze prawo troszczenia się zgodnie, według swoich możliwości, o wychowanie potomstwa zarówno fizyczne, społeczne i kulturalne, jak i moralne oraz religijne".

Kolejny wskazany numer konstytucji (nr 29) to soborowe źródło czterech kanonów (kan. $1079 \$ 2,1081,1111 \$ 1,1116 \$ 2$ ). Pierwszy z nich dotyczy dyspensowania od przeszkód małżeńskich przez kapłana lub diakona asystującego przy zawieraniu małżeństwa wiernych znajdujących się w niebezpieczeństwie śmierci przy zachowaniu warunków tam podanych ${ }^{17}$. Drugi, także z zakresu przeszkód małżeńskich, nakłada na udzielającego od nich dyspensę obowiązek powiadomienia

\footnotetext{
16 Sobór Watykański II, Konstytucja dogmatyczna o Kościele Lumen gentium, w: Sobór Watykański II, Konstytucje. Dekrety. Deklaracje, dz. cyt. (dalej: LG), nr 11.

17 Kan. $1079 \$ 2$ KPK: „W tych samych okolicznościach, o jakich w $\$ 1$, ale tylko w wypadkach, w których nie można się odnieść nawet do miejscowego ordynariusza, taką samą władzę dyspensowania posiada proboszcz, szafarz odpowiednio delegowany, a także kapłan lub diakon, asystujący przy zawieraniu małżeństwa zgodnie z kan. $1116 \$ 2 ”$ ".
} 
o tym ordynariusza miejsca i odnotowania jej w księdze małżeństw ${ }^{18}$. Następne dwa kanony znajdują się w rozdziale o formie zawarcia małżeństwa. Zawierają one dyspozycje o możliwości delegowania przez ordynariusza i proboszcza kapłanów i diakonów do asystowania przy zawieraniu małżeństw ${ }^{19}$ oraz o sytuacji braku uprawnionego do asystowania, jednak przy obecności kapłana bez wymaganej delegacji ${ }^{20}$. W przywołanych tutaj normach kodeksowych pojawia się wszędzie osoba diakona jako asystującego przy zawieraniu małżeństwa. $\mathrm{Na}$ niego właśnie wskazuje to soborowe źródło. Wśród wymienionych w nim jego zadań znajduje się „,asystowanie i błogosławienie w imieniu Kościoła związków małżeńskich"21.

Obszerna treść numeru 41 Konstytucji dogmatycznej o Kościele Lumen gentium wpłynęła na cytowany już paragraf pierwszy kanonu 1055, gdzie znajdujemy definicję małżeństwa chrześcijańskiego, na numer czwarty kanonu 1063, gdzie prawodawca stwierdza, iż pomoc świadczona małżonkom przez własną wspólnotę kościelną służyć będzie osiąganiu w rodzinie życia coraz bardziej świętego i doskonałego, oraz na kanon 1134, w którym czytamy: „Z ważnego małżeństwa powstaje między małżonkami węzeł, z natury swej wieczysty i wyłączny. W małżeństwie chrześcijańskim małżonkowie zostają ponadto przez specjalny sakrament wzmocnieni i jakby konsekrowani do obowiązków swego stanu i godności”.

\footnotetext{
18 Kan. 1081 KPK: „Proboszcz albo kapłan lub diakon, o którym w kan. $1079 \$ 2$, powinien o udzieleniu dyspensy w zakresie zewnętrznym natychmiast powiadomić ordynariusza miejsca. Winna być ona również odnotowana w księdze małżeństw”. 19 Kan. 1111 \$ 1 KPK: „Ordynariusz i proboszcz, dopóki ważnie sprawują swój urząd, mogą delegować kapłanom i diakonom również ogólne upoważnienie do asystowania przy zawieraniu małżeństw w granicach swego terytorium”.

20 Kan. $1116 \$ 2$ KPK: „W obydwu wypadkach, gdyby był osiągalny inny kapłan lub diakon, który mógłby być obecny, powinien być poproszony i razem ze świadkami być przy zawieraniu małżeństwa, z zachowaniem zasady ważności małżeństwa wobec samych świadków".

21 LG, nr 29.
} 


\section{Konstytucja duszpasterska o Kościele w świecie współczesnym Gaudium et spes}

Konstytucja duszpasterska Gaudium et spes to trzecia z konstytucji soborowych, którą widzimy w źródłach prawa małżeńskiego w Kodeksie prawa kanonicznego z 1983 roku. Cztery jej numery stanowią źródła 7 kanonów. Cztery z nich znajdują się w części ogólnej, wprowadzającej w prawo małżeńskie. Są to kanony: $1055 \$ 1^{22}, 1056^{23}, 1057$ $\$ 1^{24}$ oraz $1061 \S 1^{25}$. Dla trzech pierwszych inspiracją stał się numer 48 tej konstytucji, dla ostatniego zaś numer 49. Obydwa znajdują się w rozdziale siódmym soborowego dokumentu zatytułowanym „Eschatologiczny charakter Kościoła pielgrzymującego i jego jedność z Kościołem w niebie”. Ich treść akcentuje miejsce małżonków w ludzie Bożym i ich zadania. Istotne cele małżeństwa chrześcijańskiego nie mają tylko wymiaru ziemskiego, ale i eschatyczny, przygotowujący do życia wiecznego.

Kolejne normy kodeksowe to kanon 1063 z numerami 1, 2 i $4^{26}$, wymieniający sposoby, przez które duszpasterze mają troszczyć się o stan

${ }^{22}$ Kan. 1055 \$1 KPK: „Małżeńskie przymierze, przez które mężczyzna i kobieta tworzą ze sobą wspólnotę całego życia, skierowaną ze swej natury do dobra małżonków oraz do zrodzenia i wychowania potomstwa, zostało między ochrzczonymi podniesione przez Chrystusa Pana do godności sakramentu”.

${ }^{23}$ Kan. 1056 KPK: „Istotnymi przymiotami małżeństwa są jedność i nierozerwalność, które w małżeństwie chrześcijańskim nabierają szczególnej mocy z racji sakramentu".

${ }^{24}$ Kan. 1057 \$ 1 KPK: „Małżeństwo stwarza zgoda stron między osobami prawnie do tego zdolnymi, wyrażona zgodnie z prawem, której nie może uzupełnić żadna ludzka władza”.

25 Kan. 1061 \$ 1 KPK: „Ważne małżeństwo pomiędzy ochrzczonymi nazywa się tylko zawartym, jeśli nie zostało dopełnione; zawartym i dopełnionym, jeśli małżonkowie podjęli w sposób ludzki akt małżeński przez się zdolny do zrodzenia potomstwa, do którego to aktu małżeństwo jest ze swej natury ukierunkowane i przez który małżonkowie stają się jednym ciałem”.

26 Kan. 1063 KPK: „Duszpasterze mają obowiązek troszczyć się o to, aby własna wspólnota kościelna świadczyła pomoc wiernym, dzięki której stan małżeński zachowa ducha chrześcijańskiego i będzie się doskonalił. Ta pomoc winna być 
małżeński; kanony $1134^{27}$ i $1136^{28}$ dotyczące skutków małżeństwa oraz kanon $1141 \mathrm{z}$ rozdziału normującego zagadnienie rozwiązania małżeństwa. Ten ostatni stanowi jednak, iż „małżeństwo zawarte i dopełnione nie może być rozwiązane żadną ludzką władzą i z żadnej przyczyny, oprócz śmierci”. Źródłem wymienionych w tym akapicie kanonów są następujące numery konstytucji Gaudium et spes: 47, 48, 52. Tutaj trzeba koniecznie zaznaczyć, iż treść numeru 47 wpłynęła na jeden kanon (1063 nr 1), numeru 48 na trzy kanony $(1134,1136$, 1141), zaś numeru 52 na trzy numery jednego kanonu (1063 nr 1, 2, 4).

\section{Dekret o katolickich Kościołach wschodnich Orientalium Ecclesiarum}

Dekret Orientalium Ecclesiarum ${ }^{29}$ zbudowany został z 30 numerów. Składają się one, oprócz wstępu i zakończenia, na sześć wątków tematycznych (choć nie mają numeracji): Kościoły partykularne albo obrządki, potrzeba zachowania dziedzictwa Kościołów wschodnich, patriarchowie wschodni, normy dotyczące sakramentów, kult Boży,

udzielana przede wszystkim: 1. poprzez przepowiadanie, katechezę odpowiednio przystosowaną dla małoletnich, młodzieży i starszych, także przy użyciu środków społecznego przekazu, dzięki czemu wierni otrzymają pouczenie o znaczeniu małżeństwa chrześcijańskiego, jak również o obowiązkach małżonków i chrześcijańskich rodziców; 2. przez osobiste przygotowanie do zawarcia małżeństwa, przysposabiające nupturientów do świętości ich nowego stanu i jego obowiązków; (...) 4. przez świadczenie pomocy małżonkom, ażeby wiernie zachowując i chroniąc przymierze małżeńskie, osiągali w rodzinie życie coraz bardziej święte i doskonałe". ${ }^{27}$ Kan. 1134 KPK: „Z ważnego małżeństwa powstaje między małżonkami węzeł, z natury swej wieczysty i wyłączny. W małżeństwie chrześcijańskim małżonkowie zostają ponadto przez specjalny sakrament wzmocnieni i jakby konsekrowani do obowiązków swego stanu i godności".

${ }^{28}$ Kan. 1136 KPK: „Rodzice mają najcięższy obowiązek i najpierwsze prawo troszczenia się zgodnie, według swoich możliwości, o wychowanie potomstwa zarówno fizyczne, społeczne i kulturalne, jak i moralne oraz religijne".

${ }^{29}$ Soвór Watykański II, Dekret o katolickich Kościołach wschodnich Orientalium Ecclesiarum, w: Sobór Waty Kański II, Konstytucje. Dekrety. Deklaracje, dz. cyt. (dalej: OE). 
kontakty z braćmi z Kościołów odłączonych. Jeden numer tego dekretu stał się źródłem interesującego nas tutaj kodeksowego prawa małżeńskiego. Jest to numer 18, umieszczony w części dotyczącej sakramentów. Wpłynął on na treść jednego kanonu, który dotyczy formy kanonicznej przy zawieraniu małżeństwa mieszanego ${ }^{30}$. Forma kanoniczna polega na wyrażeniu zgody małżeńskiej przez nupturientów „wobec asystującego miejscowego ordynariusza albo proboszcza, albo wobec kapłana lub diakona delegowanego przez jednego z nich; a także wobec dwóch świadków (...)"31. Jej zachowanie wymagane jest do ważnego zawarcia małżeństwa ${ }^{32}$. Kanon ten reguluje jednak sytuację, kiedy to zawierane jest małżeństwo strony katolickiej ze stroną niekatolicką obrządku wschodniego, np. z prawosławną. Jest to zrozumiałe, gdyż Kodeks prawa kanonicznego z 1983 roku obowiązuje stronę katolicką Kościoła łacińskiego ${ }^{33}$. Z kolei dekret Orientalium Ecclesiarum szerzej traktuje to zagadnienie. Chodzi w nim bowiem o zawieranie małżeństwa przez katolików wschodnich z niekatolikami wschodnimi. Wówczas przepisana prawem forma kanoniczna wymagana jest do godziwego jego zawarcia, do ważności wymagana jest jednak obecność kapłana ${ }^{34}$. Wszędzie zatem, gdzie jedna ze stron będzie stroną niekatolicką wschodnią, forma zawarcia małżeństwa wpływać będzie na jego godziwość, nie zaś ważność.

Warto także przypomnieć, że wspomniany numer 18 dekretu soborowego wymienia kapłana jako asystującego przy zawieranym małżeństwie. Kodeks prawa kanonicznego dodaje tu jeszcze diakona ${ }^{35}$. Z kolei w Kodeksie Kanonów Kościołów Wschodnich asystującym

30 Kan. $1127 \$ 1$ KPK: „Co do formy małżeństwa mieszanego należy zachować przepisy kan. 1108. Jeśli jednak małżeństwo zawiera strona katolicka ze stroną niekatolicką obrządku wschodniego, kanoniczna forma zawarcia wymagana jest tylko do godziwości; do ważności zaś konieczny jest udział świętego szafarza, z zachowaniem innych wymogów prawa”.

31 Kan. $1108 \S 1$ KPK.

32 Por. TAmżE.

33 Kan. 1 KPK: „Kanony tego Kodeksu dotyczą jedynie Kościoła łacińskiego”.

34 Por. OE, nr 18.

35 Por. kan. $1108 \S 1$ KPK. 
i błogosławiącym małżeństwo jest tylko hierarcha miejsca lub proboszcz miejsca, albo kapłan upoważniony przez jednego $\mathrm{z}$ nich $^{36}$. Nie ma tutaj diakona, ponieważ wymagane do ważnego zawarcia małżeństwa błogosławieństwo może być dokonane wyłącznie przez kapłana $^{37}$. W temacie tym papież Franciszek znowelizował kanon 1008 obowiązującego Kodeksu dla Kościoła łacińskiego. Mianowicie do jego dwóch paragrafów został dodany trzeci o brzmieniu: „Tylko kapłan ważnie asystuje przy zawieraniu małżeństwa między dwiema stronami wschodnimi lub między stroną łacińską i stroną wschodnią czy to katolicką, czy to niekatolicką" ${ }^{38}$. Jego treść została wzięta z Kodeksu Kanonów Kościołów Wschodnich ${ }^{39}$. Oznacza to, że odtąd diakon będzie mógł asystować jedynie przy małżeństwach katolików należących do Kościoła łacińskiego. Gdyby jeden z nupturientów należał do innego Kościoła sui iuris, nie ma on prawa asystowania. Niezachowanie tego wymogu skutkuje nieważnością zawieranego małżeństwa ${ }^{40}$.

\section{Dekret o ekumenizmie Unitatis redintegratio}

Kodeks prawa kanonicznego z 1893 roku normuje także zagadnienie podlegania prawu Bożemu i prawu kanonicznemu w sytuacji zawierania małżeństwa, którego choćby jedna ze stron była katolicka ${ }^{41}$.

\footnotetext{
36 Codex Canonum Ecclesiarum Orientalium auctoritate Joannis Pauli PP. II promulgatus. Kodeks Kanonów Kościołów Wschodnich, Gaudium 2002 (dalej: KKKW), kan. $828 § 1$.

37 Por. U. Nowicka, Szafarz sakramentu małżenstwa. Studium historyczno-prawne, Warszawa 2007, s. 186-192.

38 Franciscus, Litterae apostolicae motu proprio datae De Concordia inter Codices, quibus nonnulle normae Codicis Iuris Canonici immutantur, 31 maja 2016, AAS 108 (2016), s. 602-606.

39 Por. kan. 828 KKKW.

40 Więcej na ten temat: H. STawniak, Modyfikacje przepisów dotyczacych formy zawarcia małżenstwa wprowadzone przez papieża Franciszka, w: Chrzest i małżeństwo - harmonizacja ustawodawstwa, H. STAwnIAK, R. KAMIŃsKi (red.), Warszawa 2018, s. 87-107.

41 Por. kan. 1059 KPK.
} 
Soborowym źródłem tego kanonu, przynajmniej jego części, jest numer 16. Dekretu o ekumenizmie Unitatis redintegratio ${ }^{42}$. Czytamy w nim: „Ponadto Kościoły Wschodnie już od samego początku kierowały się własnymi normami ustalonymi przez świętych Ojców i przez synody oraz sobory powszechne. Skoro więc pewna różnorodność w obyczajach i zwyczajach wcale nie przeszkadza jedności Kościoła, lecz raczej przydaje mu blasku i w znacznym stopniu przyczynia się do spełnienia jego posłannictwa, Święty Sobór, dla uniknięcia wszelkich wątpliwości, oznajmia, jak to już wspomniano, że Kościoły Wschodu, pomne na konieczną jedność całego Kościoła, mają swobodę kierowania się własnymi normami (disciplina), jako bardziej odpowiadającymi charakterowi swoich wiernych i bardziej przydatnymi dla dobra ich dusz. Dokładne przestrzeganie tej tradycyjnej zasady, której nie zawsze się trzymano, stanowi jeden $\mathrm{z}$ koniecznych warunków wstępnych przywrócenia jedności”. Cytowany fragment dekretu został umieszczony w rozdziale trzecim, zatytułowanym „Kościoły i wspólnoty kościelne odłączone od rzymskiej Stolicy Apostolskiej”. Takie umiejscowienie pozwala lepiej zrozumieć jego treść i zastosowanie. Biorąc pod uwagę wspomniane źródło, treść kanonu 1059 łatwiej jest odnieść do małżeństwa katolicko-akatolickiego, gdzie stroną akatolicką jest wierny należący do jakiegoś Kościoła lub wspólnoty wschodniej. W przypadku małżeństwa pomiędzy katolikami sprawa zachowania prawa Bożego i kanonicznego jest jasna. W przypadku natomiast małżeństwa katolicko-akatolickiego prawodawca poleca uszanowanie zwyczajów i tradycji wymienionych społeczności kościelnych. W tym temacie warto również przywołać Dyrektorium ekumeniczne, które poleca, by każdy małżonek w takim małżeństwie starał się lepiej poznać przekonania religijne drugiej strony, a także naukę i praktyki religijne Kościoła i wspólnoty kościelnej, do której ona należy. Będzie to służyć większemu wzajemnemu zrozumieniu

42 Sobór WATYKAŃski II, Dekret o ekumenizmie Unitatis redintegratio, w: SobóR WAтүкаŃski II, Konstytucje. Dekrety. Deklaracje, dz. cyt. (dalej: UR), nr 16. 
jedności ${ }^{43}$. Natomiast „W okresie przygotowawczym [do zawarcia małżeństwa] wysiłek obojga, zmierzający do tego, by zrozumieć tradycje religijno-kościelne każdego z nich, oraz poważne studium istniejących różnic, mogą przyczynić się do uczciwości, do miłości i do większego zrozumienia tych rzeczywistości, jak też samego małżeństwa jako takiego" 44 .

Interesujący nas tutaj kanon 1059 zawiera także inne wątki, które zostały pominięte, gdyż ich źródłem nie jest dekret Unitatis redintegratio.

\section{Dekret o pasterskich zadaniach biskupów w Kościele Christus Dominus}

Wymieniony w tytule tego punktu soborowy dekret jest źródłem pierwszego paragrafu kanonu 1078 Kodeksu prawa kanonicznego. Norma ta stanowi, że „ordynariusz miejsca może swoich podwładnych gdziekolwiek przebywających oraz wszystkich aktualnie przebywających na własnym jego terytorium dyspensować od wszystkich przeszkód z prawa kościelnego, z wyłączeniem tych, od których dyspensa jest zarezerwowana Stolicy Apostolskiej” ${ }^{35}$. Z kolei będący jej źródłem numer ósmy dekretu głosi: „Poszczególnym biskupom diecezjalnym w szczegółowych przypadkach przysługuje możliwość dyspensowania od ogólnego prawa kościelnego tych wiernych, w stosunku do których zgodnie z normami prawa sprawują władzę, ilekroć uważają, iż przyniesie im to duchowy pożytek, chyba że najwyższa władza kościelna uczyniła specjalne zastrzeżenie" ${ }^{36}$. Jak łatwo zauważyć, sens obu tych tekstów jest identyczny, choć używają nieco innych słów, co jest zrozumiałe, bo przepis prawny ma swoje, specyficzne określenia.

\footnotetext{
43 Por. Papieska Rada ds. Jedności Chrześcijan, Dyrektorium ekumeniczne, 25 marca 1993, nr 149.

44 TAMŻE.

45 Kan. $1078 \$ 1$ KPK.

46 Sobór WATYкAŃski II, Dekret o pasterskich zadaniach biskupów w Kościele Christus Dominus, w: Sobór Waty каński II, Konstytucje. Dekrety. Deklaracje, dz. cyt., nr 8 b.
} 
Oprócz podkreślenia władzy udzielania dyspens nupturientom przez ordynariusza miejsca, wskazano jej ograniczenie w postaci dyspens, które w zwyczajnych warunkach mogą być udzielane jedynie przez Stolicę Apostolską. Należą do nich dyspensy od przeszkody święceń, wieczystego ślubu publicznego czystości złożonego w instytucie zakonnym na prawie papieskim oraz przeszkody występku ${ }^{47}$.

Tematyka tego fragmentu dekretu Christus Dominus umieszczona została w jego rozdziale pierwszym zatytułowanym „Biskupi i Kościół Powszechny”, w części drugiej „Biskupi a Stolica Apostolska”.

\section{Dekret o apostolstwie świeckich Apostolicam actuositatem}

Kanon 1055 Kodeksu prawa kanonicznego jest pierwszym ze 111 kanonów normujących sakrament małżeństwa. Z racji tego umiejscowienia podaje on definicję i cele małżeństwa: „Małżeńskie przymierze, przez które mężczyzna i kobieta tworzą ze sobą wspólnotę całego życia, skierowaną ze swej natury do dobra małżonków oraz do zrodzenia i wychowania potomstwa, zostało między ochrzczonymi podniesione przez Chrystusa Pana do godności sakramentu"48.

Zacytowana norma kodeksowa w swoich źródłach wymienia między innymi numer 11 Dekretu Soboru Watykańskiego II o apostolstwie świeckich Apostolicam actuositatem. Ten soborowy dokument w przywołanym numerze porusza przede wszystkim zagadnienie apostolstwa małżonków i rodzin ze szczególnym podkreśleniem $\mathrm{w}$ tej materii praw rodziców związanych $\mathrm{z}$ wychowaniem dzieci ${ }^{49}$. W komentarzu do pierwszego paragrafu kanonu 1055 Wojciech Góralski napisał, że „prawodawca, uwzględniając naukę Soboru Watykańskiego II, ujmuje cele małżeństwa całościowo, zwracając uwagę zarówno na jego elementy instytucjonalne (zrodzenie i wychowanie

\footnotetext{
47 Por. kan. $1078 \$ 2$ nr 1-2 KPK.

48 Kan. $1055 \$ 1$ KPK.

49 Por. Sobór WAtykański II, Dekret o apostolstwie świeckich Apostolicam actuositatem, w: Sobór Watykański II, Konstytucje. Dekrety. Deklaracje, dz. cyt., nr 11.
} 
potomstwa), jak i personalistyczne (dobro małżonków). Odchodząc od hierarchizacji celów małżeństwa, nowy KPK dał do zrozumienia, że w sumie tworzą one jedną zwartą i ściśle powiązaną całość (jedność w wielości)" ${ }^{\prime 20}$.

\section{Deklaracja o wychowaniu chrześcijańskim Gravissimum educationis}

Tylko jedna z trzech deklaracji Soboru Watykańskiego II, mianowicie Deklaracja o wychowaniu chrześcijańskim, stała się źródłem kodeksowego prawa małżeńskiego. Dwa jej numery, 3 i 6, wpłynęły na treść kanonu 1136: „Rodzice mają najcięższy obowiązek i najpierwsze prawo troszczenia się zgodnie, według swoich możliwości, o wychowanie potomstwa zarówno fizyczne, społeczne i kulturalne, jak i moralne oraz religijne". Kanon ten znajduje się w rozdziale ósmym tytułu siódmego dotyczącego małżeństwa, który normuje skutki zawartego małżeństwa. Posiada on także inne soborowe źródła, o czym już była mowa. Przywoływany tutaj dokument stwierdza, że „ponieważ rodzice dali życie dzieciom, w najwyższym stopniu zobowiązani są do wychowania i dlatego należy ich uważać za pierwszych i najlepszych wychowawców” "51; i dalej: „(...) do rodziców należy podstawowy i niezbywalny obowiązek oraz prawo wychowywania dzieci" ${ }^{2}$. Choć norma kodeksowa o tym nie wspomina, deklaracja Gravissimum educationis wyraźnie podkreśla, iż tego wychowawczego obowiązku żadna władza nie może rodziców pozbawiać, a wręcz przeciwnie, ma ich w tym wspierać ${ }^{53}$.

50 W. Góralski, Komentarz do kan. 1055, w: J. KRukowski (red.), Komentarz do Kodeksu Prawa Kanonicznego, t. III/2, ks. IV: Uświęcające zadanie Kościoła, Poznań 2011, s. 252.

51 Sobór WATYкаŃski II, Deklaracja o wychowaniu chrześcijańskim Gravissimum educationis, w: Sobór Watykański II, Konstytucje. Dekrety. Deklaracje, dz. cyt., nr 3.

52 TAMŻE, nr 6.

53 Por. TAmże, nr 3. 


\section{Zakończenie}

Powyżej przedstawiona bardzo ogólna analiza źródeł prawa małżeńskiego w Kodeksie prawa kanonicznego z 1983 roku każe wyciągnąć jeden narzucający się wniosek: Sobór Watykański II wpłynął na kształt obecnie obowiązującego prawa kodeksowego. Wskazać można kanony (1061 §1, 1063 nr 1 i 4), których jedynym źródłem, oprócz odwołania do Kodeksu prawa kanonicznego z 1917 roku, są właśnie dokumenty soborowe.

Zestawiając teksty kanonów z odpowiadającymi im dokumentami soborowymi, łatwo wykazać ich wzajemne powiązanie, nawet jeśli nie znajdziemy w tych pierwszych bezpośrednich cytatów $\mathrm{z}$ tych drugich. Można nawet powiedzieć, że dokumenty soborowe pomagają lepiej zrozumieć treść zawartą w danej normie kodeksowej. Z pewnością bardziej szczegółowa analiza soborowych źródeł prawa małżeńskiego jeszcze lepiej ukazałaby ich powiązanie z Kodeksem prawa kanonicznego i potwierdziła myśl Jana Pawła II, że jest on jakby pasem transmisyjnym przenoszącym na język kanonistyczny doktrynę soborową ${ }^{54}$.

\section{Conciliar roots of marital law in the Canon Law Code of 1983}

\section{Summary}

Documents of the Second Vatican Council became essential root of the Canon Code Law of 1983. There is a number of references to conciliar constitutions, decrees and declarations in each Canon Book. This is true also in regard to the marital law included in Canons 1055-1165. Amongst sources which were inspirations for the aforementioned marital law there were the following constitutions: Sacrosanctum Concilium, Lumen gentium, and Gaudium et spes; and decrees: Orientalium...., Unitatis..., Christus... and Apostolicum and also Gravissimum. Lawmaker makes 34 references to these

\footnotetext{
54 Por. Jan PaweŁ II, Konstytucja apostolska Sacrae disciplinae leges, Rzym, 25 stycznia 1983, w: KPK, s. 13.
} 